\title{
Opredelitev slovenskega dopolnilnega zdravstvenega zavarovanja kot storitev splošnega gospodarskega pomena
}

\author{
Bruno Nikolić \\ Univerza v Ljubljani, Fakulteta za upravo, Slovenija \\ bruno.nikolic@fu.uni-lj.si
}

\section{IZVLEČEK}

Dopolnilno zdravstveno zavarovanje je $\mathrm{v}$ slovenski zakonodaji opredeljeno kot dejavnost v javnem interesu, ki je neločljiv in bistven element sistema socialne varnosti ter kot tak uresničuje identične cilje kot obvezno zdravstveno zavarovanje - finančno varnost prebivalstva pred visokimi zdravstvenimi izdatki ter primeren in pravičen dostop do učinkovite in kakovostne zdravstvene oskrbe. Države članice EU pogosto uvajajo različne regulatorne ukrepe, s katerimi varujejo javni interes na področju gospodarskih dejavnosti. Ti ukrepi so pogosto v nasprotju s pravnim redom EU (pravili o delovanju notranjega trga in konkurenčno zakonodajo), kar je z vidika EU načeloma nedopustno. Cilj članka je opredelitev slovenskega dopolnilnega zdravstvenega zavarovanja kot storitev splošnega gospodarskega pomena, ki državam članicam širi meje avtonomnega urejanja oziroma omogoča sprejem regulatornih ukrepov, ki niso skladni s pravili o delovanju notranjega trga in konkurenčno zakonodajo EU.

Ključne besede: financiranje zdravstvenega varstva, dopolnilno zdravstveno zavarovanje, storitev splošnega gospodarskega pomena, javni interes

$J E L: K 32$

\section{Uvod}

Zdravstveno zavarovanje je zavarovanje za izgubo, ki nastane zavarovancu v primeru bolezni, poškodbe, poroda ali smrti. Posameznikom, ki so vključeni v sistem zdravstvenega zavarovanja, zagotavlja socialno varnost pred negotovostjo, ki jih lahko doleti ob nastanku zavarovalnega dogodka. Nekatere države uporabljajo zdravstveno zavarovanje na sistematski ravni in prek predplačniških prispevkov financirajo sistem zdravstvenega varstva. $V$ to skupino uvrščamo tudi Slovenijo, kjer se sistem zdravstvenega varstva financira iz dveh virov, to je iz javnih in zasebnih sredstev. Levji delež javnih sredstev, 


\section{Bruno Nikolić}

okoli 75 \%, znaša socialno oziroma obvezno zdravstveno zavarovanje. ${ }^{1}$ Največji vir zasebnega financiranja pa so prostovoljna zdravstvena zavarovanja (nekaj več kot $50 \%$ zasebnih sredstev), katerih več kot $90 \%$ obsega dopolnilno zdravstveno zavarovanje (ZZZS, 2013, str. 144; SURS, 2013). ${ }^{2}$

Zdravstveno varstvo je temeljni element evropske socialne države. Kljub temu da države članice EU različno urejajo to področje, je skupna značilnost vseh ureditev zasledovanje univerzalnega dostopa, ki temelji na načelu solidarnosti. Države članice z vstopom v EU nanjo prenesejo izvrševanje dela suverenih pravic, kar z drugimi besedami pomeni, da se odrečejo delu svojih pristojnosti in jih v večji ali manjši meri prenesejo na institucije EU. Področje zdravstvenega varstva je na začetku razvoja Evropske gospodarske skupnosti spadalo povsem v pristojnost držav članic. Rimska pogodba, ki je stopila v veljavo leta 1958, ni vidneje posegala na področje zdravstva. ${ }^{3}$ Razvoj Evropske gospodarske skupnosti in kasneje EU je skozi čas na številnih področjih dodobra zabrisal meje med pravnim redom držav članic in pravom EU. To se odraža tudi na področju zdravstvenega varstva. Zdravstveno varstvo je postajalo vse pomembnejši interes EU, kar je dobro razvidno iz erozije pristojnosti držav članic na tem področju. ${ }^{4}$ Glavno vlogo pri tem imajo reforme ustanovitvenih pogodb, sekundarni pravni viri, razvoj interpretacije temeljnih načel in progresivna vloga Sodišča EU. ${ }^{5}$ Tudi pri organiziranju sistema financiranja zdravstvenega varstva, države članice niso povsem avtonomne. Njihova avtonomija je v največji meri odvisna od načina organizacije sistema financiranja in njegove pravne ureditve. Države članice pogosto uvajajo različne regulatorne ukrepe, s katerimi varujejo javni interes na področju financiranja in izvajanja sistema zdravstvenega varstva. Ti ukrepi pogosto prestopijo prag avtonomnosti, ki jim ga dopušča evropska zakonodaja, kar pa je z vidika EU nedopustno. ${ }^{6}$

1 Preostali javni viri so proračunska sredstva države in občin.

2 Preostali zasebni viri so neposredna plačila prebivalstva za zdravstvene storitve (okoli 45 \% zasebnih sredstev) ter donacije raznih dobrodelnih ustanov in drugih donatorjev.

3 Zdravstvo in zdravje, predvsem glede njegove zaščite, so omenjali zgolj trije členi: 36, 48(3) in 56(1).

4 Van de Gronden (2013, str. 128) piše o evropeizaciji na področju zagotavljanja in organiziranja socialnih storitev v splošnem interesu. Izraz evropeizacija uporablja tudi Szyszczak (2013, str. 321), s katerim pojasnjuje nastanek mreže uveljavljenih in novih akterjev, ki ustvarjajo koncept socialnih storitev splošnega pomena, ter nove pristojnosti Evropske komisije v obliki nezavezujoče zakonodaje in »mehkega« upravljanja (angl. soft governance).

5 Za podrobnejšo razpravo o razvoju vpliva pravnega reda EU na socialne storitve od začetka integracij do Lizbonske pogodbe glej Damjanovic \& de Witte (2009).

6 Slovensko dopolnilno zdravstveno zavarovanje se je že znašlo pred Sodiščem EU. Evropska komisija je $v$ tožbi Sloveniji očitala neizpolnitev obveznosti iz člena 8(3) Prve direktive o neživljenjskem zavarovanju ter iz členov 29 in 39 Tretje direktive o neživljenjskem zavarovanju ter tudi iz členov 56 in 63 PDEU (Sodba SEU C-185/11 z dne 26. januarja 2012, odst. 19). Glede očitka v zvezi s kršitvijo člena 8(3) Prve direktive o neživljenjskem zavarovanju ter 29. in 39. člena Tretje direktive o neživljenjskem zavarovanju je Sodišče EU ugotovilo, da Republika Slovenija z nepravilno in nepopolno implementacijo Prve in Tretje direktive o neživljenjskem zavarovanju ni izpolnila obveznosti iz člena 8(3) Prve direktive o neživljenjskem zavarovanju ter iz členov 29 in 39 Tretje direktive o neživljenjskem zavarovanju (Sodba SEU C-185/11 z dne 26. januarja 2012, odst. 27). Očitek v zvezi s kršitvijo členov 56 in 63 PDEU je Sodišče EU zavrglo na podlagi ugotovitev, da v obravnavani zadevi ni koherentnosti med povzetkom očitka, da Republika Slovenija krši člena 56 in 63 PDEU, ter tožbenim predlogom, v okviru katerega Evropska komisija Sloveniji očita nepravilen in nepopoln prenos Prve in Tretje direktive o neživljenjskem zavarovanju (Sodba SEU C-185/11 z dne 26. januarja 2012, odst. 30). Sodišče je tožbeni zahtevek zavrglo kot nedopusten, kar pomeni, da o zadevi ni odločalo meritorno. 
Na pravno ureditev zdravstvenega varstva, kamor spada tudi sistem financiranja zdravstvenega varstva, ima v smislu pravnega reda EU izredno velik vpliv koncept storitve splošnega pomena (angl. Service of General Interest SGI). Opredelitev posameznih segmentov zdravstvenega varstva v kontekstu storitve splošnega pomena pod določenimi pogoji izključuje domet pravil notranjega trga in konkurenčne zakonodaje EU (negospodarske storitve splošnega pomena) oziroma upravičuje regulatorne posege držav članic, ki niso skladni s pravili o delovanju notranjega trga in konkurenčno zakonodajo EU (storitve splošnega gospodarskega pomena). Cilj prispevka je opredelitev slovenskega dopolnilnega zdravstvenega zavarovanja kot storitev splošnega gospodarskega pomena, ki državam članicam širi meje avtonomnega urejanja oziroma omogoča sprejem regulatornih ukrepov, ki niso skladni s pravili o delovanju notranjega trga in konkurenčno zakonodajo EU. Takšna opredelitev nacionalnemu zakonodajalcu omogoča sprejem regulatornih ukrepov v javnem interesu, ki krepijo socialno dimenzijo na področju financiranja zdravstvenega varstva.

\section{Koncept storitve splošnega pomena}

\subsection{Storitve splošnega pomena}

Storitve splošnega pomena oziroma javne službe, kot jih tudi imenujemo, so pravni koncept, ki zajema vrsto različnih dejavnosti. Mednje uvrščamo obsežne mrežne gospodarske panoge, kot so energetika, telekomunikacije, promet, avdiovizualne in poštne storitve, izobraževanje, oskrbo z vodo, ravnanje z odpadki ter ne nazadnje tudi zdravstvene in socialne storitve. Te storitve imajo pomembno vlogo pri zagotavljanju socialne, ekonomske in ozemeljske kohezije celotne EU ter so bistvene za njen trajnostni razvoj glede višje stopnje zaposlenosti, socialne vključenosti, ekonomske rasti in kakovosti okolja (Evropska komisija, 2007, str. 3). Storitve splošnega pomena lahko nadalje opredelimo kot storitve gospodarske narave - storitve splošnega gospodarskega pomena in kot storitve negospodarske narave negospodarske storitve splošnega pomena.

\subsection{Negospodarske storitve splošnega pomena}

Med negospodarske storitve splošnega pomena (negospodarske javne službe) uvrščamo naslednje dejavnosti: davčni sistem, policijo, sodstvo, sisteme socialne varnosti ipd. Za te dejavnosti velja, da spadajo v izključno pristojnost držav članic, kar v smislu pravnega reda EU pomeni, da niso predmet konkurenčne zakonodaje EU in pravil, ki urejajo delovanje notranjega trga (Evropska komisija, 2007, 4; 2. člen Protokola št. 26 o storitvah splošnega pomena, ki je dodan Lizbonski pogodbi (2007/C 306/01)). Obseg dejavnosti, ki so opredeljene kot negospodarske storitve splošnega pomena, se v pravnem

Glede na zapisano lahko Evropska komisija ponovno vloži tožbo zoper Slovenijo in ob ustrezni dopolnitvi tožbenega zahtevka doseže meritorno obravnavo zadeve. 
redu EU skozi čas vztrajno krči, kar hkrati zmanjšuje avtonomijo držav članic na tem področju. Pri tem igra poglavitno vlogo Evropska komisija, ki z »mehkim pristopom« (nezavezujočimi pravnimi akti) širi domet evropske zakonodaje (Neergard, 2013, 209).

\subsection{Storitve splošnega gospodarskega pomena}

Koncept storitve splošnega gospodarskega pomena se nanaša na tržne storitve, za katere države članice zaradi splošnega pomena določijo posebne obveznosti zagotavljanja javnih storitev. Mednje uvrščamo dejavnosti, ki jih zagotavljajo velike mrežne gospodarske panoge (telekomunikacije, poštne storitve, elektrika, plin, promet itd.) in druge storitve splošnega gospodarskega pomena (upravljanje z odpadki, oskrba s pitno vodo, RTV itd.) (Pečarič in Bugarič, 2011, 166). Storitve splošnega gospodarskega pomena obravnavajo domala vsi segmenti pravnega reda EU. Njihovo opredelitev zasledimo v primarni zakonodaji, natančneje v Pogodbi o delovanju Evropske unije ( nadaljevanju PDEU) in Protokolu št. 26 o storitvah splošnega pomena, ki je priložen Lizbonski pogodbi. PDEU v členu 106(2) navaja, da morajo podjetja, pooblaščena za opravljanje storitev splošnega gospodarskega pomena, oziroma podjetja, ki imajo značaj dohodkovnega monopola, ravnati po pravilih o delovanju notranjega trga in konkurenčni zakonodaji EU. Vendar pa ta člen določa tudi izjeme od tega pravila v primeru, če bi uporaba pravil o delovanju notranjega trga in konkurenci pravno ali dejansko ovirala izvajanje nalog, ki so takim podjetjem dodeljene. Ta izjema se uporabi le, kadar ni vpliva na razvoj trgovine v obsegu, ki bi bil v nasprotju z interesi EU (Evropska komisija, 2011, 3. odstavek).

Poleg primarne zakonodaje urejajo storitve splošnega gospodarskega pomena tudi sekundarni pravni viri. Najpomembnejši med njimi je Direktiva o storitvah na notranjem trgu. ${ }^{7}$ Večina sekundarnih pravnih virov s področja storitev splošnega gospodarskega pomena je odraz liberalizacijske politike EU, ki je potekala po tako imenovanem sektorskem pristopu, v sklopu katerega je Evropska komisija z različnimi sekundarnimi zakonodajnimi akti uredila posebnosti izvajanja posameznih storitev splošnega gospodarskega pomena (področje energetike, telekomunikacij, transporta in drugih, na omrežje vezanih gospodarskih dejavnosti) (Brezovnik, 2008, 40). ${ }^{8}$

7 Direktiva 2006/123/ES Evropskega parlamenta in Sveta z dne 12. decembra 2006 o storitvah na notranjem trgu (Uradni list L 376/37, 27. 12. 2006).

8 Direktiva 96/92/ES Evropskega parlamenta in Sveta z dne 19. 6. 1996 o skupnih pravilih notranjega trga z električno energijo (Uradni list L 027, 30. 1. 1997); Direktiva 97/67/ ES Evropskega parlamenta in Sveta z dne 15. decembra 1997 o skupnih pravilih za razvoj notranjega trga poštnih storitev v Skupnosti in za izboljšanje kakovosti storitve (Uradni list L 15, 21. 1. 1998); Direktiva 2002/22/ES Evropskega parlamenta in Sveta z dne 7. marca 2002 o univerzalnih storitvah in pravicah uporabnikov v zvezi z elektronskimi komunikacijskimi omrežji in storitvami (Direktiva o univerzalni storitvi) (Uradni list EU L 108, 24. 4. 2002); Direktiva 97/33/ES Evropskega parlamenta in Sveta z dne 30. junija 1997 o medomrežnem povezovanju v telekomunikacijah glede zagotavljanja univerzalnih storitev in interoperabilnosti z uporabo načel zagotavljanja odprtosti omrežij (Uradni list EU L 199, 26. 7. 1997) itd. 
Poleg primarne in sekundarne zakonodaje lahko zasledimo tudi druge oblike zavezujočih in nezavezujočih pravnih aktov, s katerimi institucije in drugi organi EU posegajo na področje storitev splošnega gospodarskega pomena.

Kljub obsežni literaturi, ki obravnava storitve splošnega gospodarskega pomena, in velikemu prizadevanju vseh treh vej oblasti EU za njihovo natančno opredelitev , kar se odraža na številnih aktih s tega področja, še zmeraj ni bila izoblikovana povsem jasna pravna definicija tega koncepta.

\subsection{Socialne storitve splošnega pomena}

Za področje zdravstvenega varstva je pomemben tudi koncept socialnih storitev splošnega pomena (angl. social service of general interest - SSGI). ${ }^{10}$ Tako primarna kot sekundarna zakonodaja tega pojma ne opredeljujeta. Gre za novejši koncept v družini storitev splošnega pomena, ki ga v zavezujočih pravnih aktih EU ne zasledimo. V politični agendi EU se prvič pojavi v Poročilu Evropske komisije o zasedanju Evropskega sveta v Laeknu - Storitve splošnega pomena iz leta 2001. V pravnem kontekstu pa ga prvič zasledimo v nezavezujočem sporočilu Evropske komisije z naslovom Izvajanje programa Skupnosti iz Lizbone: Socialne storitve splošnega pomena v Evropski uniji, ${ }^{11}$ ki poleg storitev zdravstvenega varstva $v$ ožjem smislu ${ }^{12}$ opredeljuje tudi dve veliki skupini socialnih storitev, kamor uvrščamo obvezna in dopolnilna zdravstvena zavarovanja. ${ }^{13}$

Sporočilo nadalje pojasnjuje, da socialne storitve splošnega pomena v pravu EU ne predstavljajo samostojne pravne kategorije. ${ }^{14}$ Socialne storitve splošnega pomena v pravnem smislu uvrščamo, odvisno od njihove narave dejavnosti, med storitve splošnega gospodarskega pomena ali pa med negospodarske storitve splošnega pomena. Samo dejstvo, da je dejavnost označena kot socialna dejavnost, še ne pomeni, da je hkrati ni mogoče označiti kot gospodarsko dejavnost. Socialne storitve splošnega pomena, ki imajo gospodarsko naravo, uvrščamo med storitve splošnega gospodarskega pomena (Evropska komisija, 2010, str. 17). Zanje velja, da mora biti zagotovljena

9 Za ponazoritev navajamo le nekaj primerov: Komisija EU: Zelena knjiga o storitvah splošnega pomena, Bruselj, 21. 5. 2003, COM(2003) 270 končno; Sporočilo Komisije: Bela knjiga o storitvah splošnega pomena, Bruselj, 12. 5. 2004, COM (2004) 374 končno; Resolucija Evropskega parlamenta z dne 5. julija 2011 o prihodnosti socialnih storitev splošnega pomena (2009/2222(INI)); Resolucija Evropskega parlamenta z dne 14. marca 2007 o socialnih storitvah splošnega pomena v Evropski uniji (2006/2134(INI)); Primeri: zadeva C-393/92, Almelo, [1993], zadeva C-320/91, Corbeau, [1993], zadeva C-340/99, TNT Traco, [2001], zadeva C-393/92, Almelo, [1993], zadeva C-475/99, Ambulanz Glöckner, [2001], zadeva C-41/90, Höfner and Elser, [1991], zadeva C-266/96, Corsica Ferries, [1998]...

10 Za razvoj in boljše razumevanje ter razlikovanje vseh konceptov splošnega pomena glej Neergaard (2013).

11 Sporočilo Komisije: Izvajanje programa Skupnosti iz Lizbone: Socialne storitve splošnega pomena v Evropski uniji (COM(2006) 177, z dne 26. 4. 2006).

12 Te niso zajete s tem Sporočilom Komisije.

13 Natančneje v prvo skupino: "zakonsko določene in komplementarne oziroma dopolnilne sisteme socialne varnosti v različnih organizacijskih oblikah (vzajemni ali poklicni), ki zajemajo temeljna življenjska tveganja, povezana z zdravjem, starostjo, nesrečami pri delu, brezposelnostjo, upokojitvijo in invalidnostjo«.

14 Tako meni tudi Szyszczak (2013). 


\section{Bruno Nikolić}

skladnost njihovega načina organizacije in delovanja s pravili notranjega trga in konkurenčno zakonodajo EU. ${ }^{15}$

Slika 1: Domet pravnega reda EU

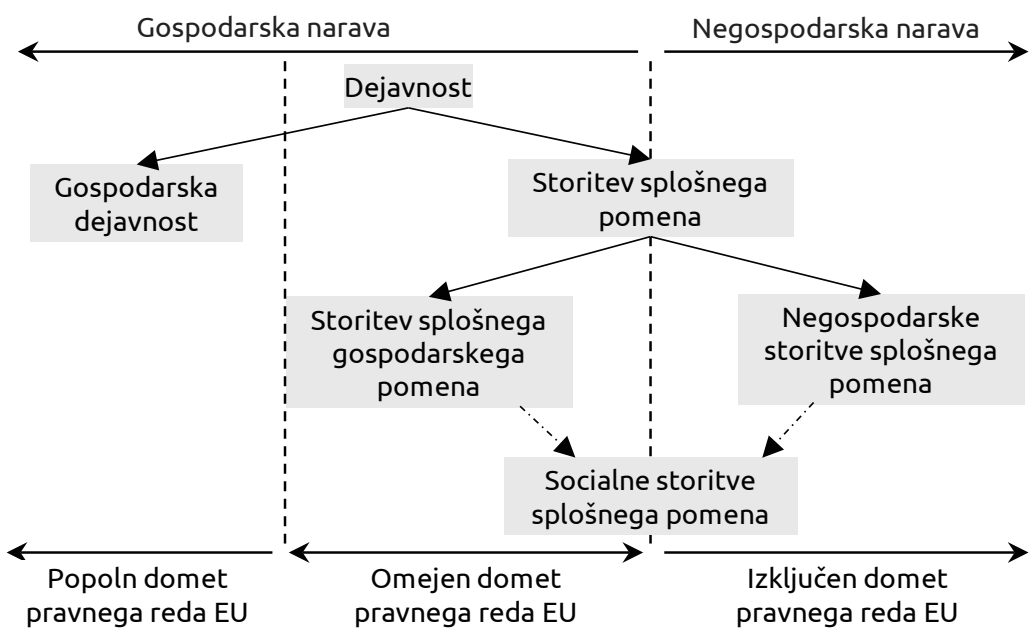

Vir: prirejeno po Hatzopoulos (2011, str.12).

\section{Pristojnosti in pogoji opredeljevanja dejavnosti dopolnilnega zdravstvenega zavarovanja kot storitve splošnega gospodarskega pomena}

Storitve splošnega gospodarskega pomena se razlikujejo od običajnih gospodarskih storitev, saj država meni, da jih je treba opravljati tudi v primeru nezadostne tržne spodbude. S tem se ne zanika, da je trg v nekaterih primerih najboljši mehanizem zagotavljanja teh storitev, temveč državam zgolj dopušča, da v primeru, če menijo, da so nekatere storitve v splošnem interesu in jih tržne sile ne zmorejo uspešno zadovoljiti, poskrbijo za zagotovitev teh storitev pod posebnimi pogoji v obliki obveznosti zagotavljanja storitve splošnega pomena (Evropska komisije, 2001, točka 14).

Prvi pogoj za opredelitev dejavnosti kot storitve splošnega gospodarskega pomena je, da ima dejavnost gospodarsko naravo. Drugi pogoj za opredelitev zahteva, da se z dejavnostjo zagotavljajo za družbo eksistenčno pomembne storitve (dobrine), zato družba upošteva, da je preskrba s temi storitvami (dobrinami) v javnem interesu in jih podvrže posebnemu pravnemu režimu.

Pri opredeljevanju dejavnosti kot storitve splošnega gospodarskega pomena z vidika evropske zakonodaje je pomembno vprašanje distribucije kompetenc med državami članicami in EU. Države članice imajo pri opredeljevanju

15 Neergardova (2013, str. 207-210) ponazarja razmerje med storitvami splošnega pomena, storitvami splošnega gospodarskega pomena (oziroma negospodarskimi storitvami splošnega pomena) in socialnimi storitvami splošnega pomena s sorodstvenim razmerjem med staro mamo, mamo in vnukinjo. 
storitve splošnega gospodarskega pomena široko diskrecijo, kar podpirajo tako primarna in sekundarna zakonodaja EU kot tudi sodna praksa Sodišča EU. V pravnem redu EU ne zasledimo natančne opredelitve pojma storitev splošnega gospodarskega pomena, niti pogojev, ki morajo biti izpolnjeni, da bi se lahko država članica sklicevala na obstoj in varstvo posebnega pravnega režima storitve splošnega gospodarskega pomena. ${ }^{16}$ Evropski zakonodaja tudi ne podeljuje EU posebnih pristojnosti glede storitev splošnega gospodarskega pomena. Na podlagi teh argumentov je Sodišče EU v primeru BUPA zavzelo stališče, da je opredelitev dejavnosti kot storitve splošnega gospodarskega pomena v pristojnosti držav članic. ${ }^{17} \mathrm{Na}$ področju storitev splošnega gospodarskega pomena, ki imajo naravo socialnih oziroma zdravstvenih storitev, je takšno stališče še toliko močnejše, saj imajo države članice na tem področju skoraj izključno pristojnost. ${ }^{18}$ Države članice so na podlagi člena 168(7) PDEU odgovorne za opredelitev zdravstvene politike ter organiziranje in zagotavljanje zdravstvenih storitev in zdravstvene oskrbe. Iz tega sledi, da so tudi za opredelitev obveznosti storitve splošnega gospodarskega pomena v tem okviru najprej pristojne države članice. Enako opredelitev pristojnosti na splošni ravni izraža tudi člen 14 PDEU, v skladu s katerim ob upoštevanju položaja, ki ga imajo storitve splošnega gospodarskega pomena v okviru skupnih vrednot in vloge, ki jo imajo pri pospeševanju socialne in teritorialne kohezije v EU, EU in države članice v mejah svojih pristojnosti skrbijo, da takšne službe delujejo na podlagi načel in pogojev, ki jim omogočajo izpolnjevanje njihovih nalog. ${ }^{19}$ Sodišče EU je v zadevah FFSA proti Komisiji [C-174/97, 100], Olsen proti Komisiji $[T-17 / 02,216]$ in BUPA $[T-289 / 03,169]$ zavzelo stališče, da je pristojnost EU pri opredeljevanju storitev splošnega gospodarskega pomena zelo omejena in se nanaša zgolj na iskanje očitnih napak pri presoji držav članic. ${ }^{20}$

Kljub široki diskreciji držav članic morajo biti te pri tem vseeno pazljive, da dejavnost v okoliščinah danega primera izpolnjuje v sodni praksi Sodišča EU opredeljena najnižja merila, skupna vsaki storitvi splošnega gospodarskega pomena. Ta merila od držav članic terjajo, da pri opredeljevanju dokažejo (i) gospodarsko naravo zadevne dejavnosti, (ii) da se dejavnost izvaja

16 Zadeva BUPA [T-289/03, 165].

17 Široko diskrecijsko pravico držav članic pri opredeljevanju je Sodišče EU potrdilo tudi v zadevi FFSA in drugi proti Komisiji $[T$ 106/95, 99]. Takšno stališče zasledimo tudi v Direktivi o storitvah 1(3) in številnih dokumentih Evropske komisije: Sporočilo Komisije o uporabi pravil Evropske unije o državni pomoči za nadomestilo, dodeljeno za opravljanje storitev splošnega gospodarskega pomena, 2012/C 8/02, točka 46; Sporočilo Komisije: Storitve splošnega pomena v Evropi (96/C281/03), OJ C 281/3, sekcija 26; Sporočilo Komisije: Bela knjiga o storitvah splošnega pomena, Bruselj, 12. 5. 2004, COM (2004) 374 končno, str. 5-6; Zelena knjiga o storitvah splošnega pomena, $\operatorname{COM}(2003)$ 270, sekcija 30-32, itd.

18 Glej člene 2(5), 6, 153 in168(1), (7) PDEU.

19 Zadeva BUPA [T-289/03, 167].

20 Takšno stališče je zavzela tudi Evropska komisija v Sporočilu Komisije o uporabi pravil Evropske unije o državni pomoči za nadomestilo, dodeljeno za opravljanje storitev splošnega gospodarskega pomena, 2012/C 8/02, točka 46. 
v javnem interesu, ${ }^{21}$ (iii) obstoj oblastvenega akta, s katerim je zadevnemu gospodarskemu subjektu podeljena naloga storitve splošnega gospodarskega pomena (oblastveni akt mora vsebovati jasno opredelitev obveznosti storitve splošnega gospodarskega pomena) ter (iv) univerzalno in obvezno naravo podeljene naloge. Če država tega ne stori, lahko to pomeni očitno napako, ki jo Evropska komisija mora sankcionirati. V nadaljevanju razčlenjujemo merila za opredeljevanje storitve splošnega gospodarskega pomena in v tej luči presojamo slovensko dopolnilno zdravstveno zavarovanje.

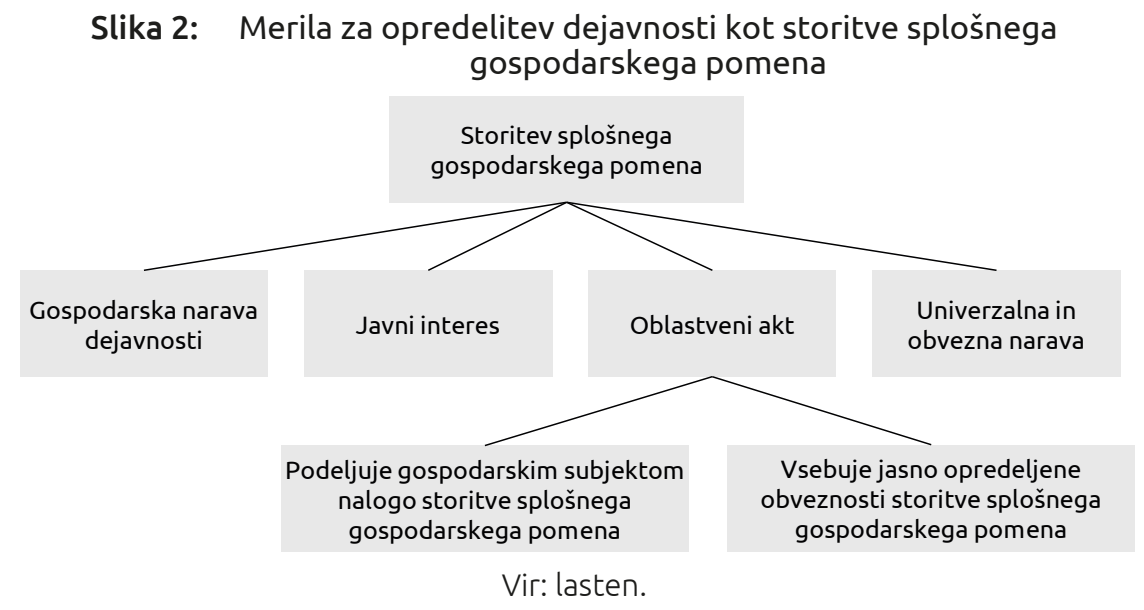

\section{Ali slovensko dopolnilno zdravstveno zavarovanje izpolnjuje merila za opredelitev dejavnosti kot storitve splošnega gospodarskega pomena}

Če želimo opredeliti slovensko dopolnilno zdravstveno zavarovanje kot storitev splošnega gospodarskega pomena, moramo dokazati, da zavarovanje izpolnjuje merila iz slike 2.

\section{a) Gospodarska narava dejavnosti}

Iz ustaljene sodne prakse Sodišča EU izhaja, da ima dejavnost gospodarsko naravo, če izpolnjuje dva kriterija: v okviru te dejavnosti se na trgu ponujajo izdelki ali storitve ${ }^{22}$ in finančno tveganje pri opravljanju dejavnosti nosi subjekt, ki to dejavnost opravlja (ponuja na trgu izdelke ali storitve). ${ }^{23}$ To ne pomeni,

21 Država ima dolžnost navesti razloge, zaradi katerih meni, da je treba zadevno storitev zaradi njenega posebnega pomena opredeliti kot storitev splošnega gospodarskega pomena in jo tako ločiti od drugih gospodarskih dejavnosti. Glej Zadevo BUPA [T-289/03, 172] in zadevo Merci Convenzionali Porto di Genova [C-179/90, 27].

22 Zadeva Cisal in INAIL [C 218/00, 23].

Nakup dobrin ali storitev na trgu ne opredeljuje (gospodarske) narave te dejavnosti per se. Za namen presoje narave dejavnosti je treba upoštevati tudi poznejšo uporabo kupljenega proizvoda, saj gospodarska ali negospodarska narava poznejše uporabe proizvoda opredeljuje tudi naravo dejavnosti nakupa (FENIN [C-205/03, 26]).

23 Zadeva Wouters C-309/99, 48-49]. 
da mora subjekt opravljati dejavnost na dobičkonosen način, ${ }^{24}$ temveč zadostuje že to, da jo lahko vsaj načeloma izvaja na takšen način (Hatzopoulos, 2011, str. 18-19). ${ }^{25}$ Slovenski sistem dopolnilnega zdravstvenega zavarovanja je dejavnost, ki jo izvajajo zdravstvene zavarovalnice po tržnih zakonitostih in s pridobitnim namenom. Dejavnost izpolnjuje oba kriterija, saj zdravstvene zavarovalnice ponujajo dopolnilno zdravstveno zavarovanje na trgu in hkrati nosijo finančno tveganje pri opravljanju te dejavnosti. Glede na oba izpolnjena kriterija lahko nedvomno potrdimo gospodarsko naravo dopolnilnega zdravstvenega zavarovanja.

\section{b) Splošni pomen oziroma javni interes}

Za opredelitev dejavnosti kot storitve splošnega gospodarskega pomena je treba dokazati, da je ponudba oziroma opravljanje storitve v splošnem oziroma javnem interesu. Zakonodajalec je v členu 62 Zakona o zdravstvenem varstvu in zdravstvenem zavarovanju ( $v$ nadaljevanju ZZVZZ) ${ }^{26}$ opredelil, da pomeni dopolnilno zdravstveno zavarovanje javni interes Republike Slovenije, saj skupaj z obveznim zdravstvenim zavarovanjem tvori sistem socialne varnosti. Samo dejstvo, da nacionalni zakonodajalec v splošnem interesu v širšem smislu določi poseben pravni režim izvajanja določene dejavnosti, načeloma ni bistveno za obstoj storitve splošnega gospodarskega pomena. ${ }^{27}$ Treba je tudi dejansko dokazati, da je izvajanje dejavnosti v javnem interesu.

Dopolnilno zdravstveno zavarovanje ni le sestavni del sistema socialne varnosti, temveč njegov neločljiv in bistven element ter kot tak uresničuje identične cilje kot obvezno zdravstveno zavarovanje - finančna varnost prebivalstva pred visokimi zdravstvenimi izdatki ter primeren in pravičen dostop do učinkovite in kakovostne zdravstvene oskrbe. Brez vključitve v dopolnilno zdravstveno zavarovanje se zdita finančna varnost pred visokimi zdravstvenimi izdatki ter primeren dostop do učinkovite in kakovostne zdravstvene oskrbe, nedosegljiva ideala. Javni interes dopolnilnega zdravstvenega zavarovanja potrjuje tudi njegova močna socialna funkcija, ki se odraža s pomočjo naslednjih argumentov:

(i) dopolnilno zdravstveno zavarovanje je pomemben in nepogrešljiv vir financiranja sistema zdravstvenega varstva;

(ii) visoka pokritost prebivalstva z dopolnilnim zdravstvenim zavarovanjem;

(iii) namen ustanovitve in narava dopolnilnega zdravstvenega zavarovanja.

24 Zadeva FFSA [C-244/94, 21].

25 Zadeva SAT Fluggesellschaft mbH v. Eurocontrol [C-364/92, 9]. Za več o razlagi drugega kriterija, ki je izredno široka (ne zahteva se dejanska konkurenca, temveč zadostuje že domnevna konkurenca), glej Sauter W. in Schapel H.: State and Market in EU Law: The Public and Private Spheres of the Internal Market before the EU Courts (Cambridge: CUP, 2009), stran 82.

26 Zakon o zdravstvenem varstvu in zdravstvenem zavarovanju (ZZVZZ), Uradni list RS, št. 9/1992.

27 Glej zadevo BUPA [T-289/03, 178]. 
i) Dopolnilno zdravstveno zavarovanje kot pomemben in nepogrešljiv vir financiranja zdravstvenega varstva

Zasebna sredstva pri financiranju zdravstvenega varstva so v leta 2011 znašala 841.743 .000 evrov, kar znaša 26,3 \% vseh izdatkov za zdravstveno varstvo. Sredstva iz prostovoljnih zdravstvenih zavarovanj so v istem letu znašala okoli 422.000 .000 evrov, kar je nekaj več kot 50 \% vseh zasebnih sredstev (ZZZS, 2013, 144). Levji delež teh sredstev predstavljajo sredstva dopolnilnega zdravstvenega zavarovanja, ki so leta 2010 znašala okoli 400.000.000 evrov, to je krepko čez $90 \%$ vseh sredstev prostovoljnih zdravstvenih zavarovanj (Šik, 2011, str. 41). ${ }^{28}$ Tako velik delež prostovoljnih oziroma dopolnilnih zdravstvenih zavarovanj v financiranju zdravstvenega varstva najdemo v EU le še v Franciji. Poleg znatnega deleža sredstev (okoli 13 \% vseh izdatkov za zdravstveno varstvo), ki kaže na izredno pomembno vlogo dopolnilnega zdravstvenega zavarovanja v sistemu zdravstvenega varstva, nosi to zavarovanje tudi breme kritja stroškov medicinske inflacije in neučinkovitosti javnega financiranja zdravstvenega varstva.

Na prevalitev bremena medicinske inflacije na dopolnilno zdravstveno zavarovanje kaže dejstvo, da se skupna prispevna stopnja obveznega zdravstvenega zavarovanja ni spremenila vse od leta 2002. Medicinska inflacija je praviloma nad stopnjo splošne inflacije, ki je v obdobju od januarja 2003 do marca 2014 znašala 34,2 \%. Na kritje bremena medicinske inflacije nakazuje tudi poslovanje zdravstvenih zavarovalnic, ki izvajajo dopolnilno zdravstveno zavarovanje. ${ }^{29}$ Triglav je v obdobju 2007-2014 dvignil premije dopolnilnega zdravstvenega zavarovanja iz 20,61 evra na 29,42 evra, kar pomeni 42,7-odstotno povišanje. Adriatic Slovenica je v obdobju 2006-2014 dvignila premije iz 20,71 evra na 29,38 evra, kar pomeni 41,8-odstotno povišanje. ${ }^{30}$ Čeprav v Sloveniji podatki o medicinski inflaciji za to obdobje niso dostopni, se dvigi premij ujemajo oziroma, tako kot je pričakovati, presegajo stopnjo splošne inflacije. Obe zdravstveni zavarovalnici sta po večini opravičevali postopno dvigovanje premij z rastjo stroškov zdravstvenih storitev in spreminjanjem deležev kritja pravic iz obveznega zdravstvenega zavarovanja. Prevalitev stroškov medicinske inflacije povečuje pomen dopolnilnega zdravstvenega zavarovanja in skladno s tem uresničevanje socialnega cilja, saj na ta način država ohranja obstojnost financiranja obveznega zdravstvenega zavarovanja ter dostopnost in kakovost zdravstvenih storitev, ki so del obveznega zdravstvenega zavarovanja.

Gospodarska kriza in recesija, ki je krizi sledila, sta prinesli vidne spremembe na področju financiranja zdravstvenega varstva. Zakonodajalec in Zavod

28 Vtem letu so iz naslova dopolnilnega zdravstvenega zavarovanja obračunali skoraj 370.000 .000 evrov odhodkov za škodne dogodke. Za več o visokem škodnem količniku dopolnilnega zavarovanja, ki je znašal leta 2006 kar 88 \%, glej Milenkovič Kramer (2009).

29 Ne moremo trditi, da je dopolnilno zdravstveno zavarovanje nosilo celotno breme medicinske inflacije, saj sta se na ta račun povečevala tudi luknja v zdravstveni blagajni in obseg sredstev neposrednih plačil uporabnikov zdravstvenih storitev.

30 Splošna inflacija je v obdobju 2006-2014 znašala 20,4 \%. 
za zdravstveno zavarovanje Slovenije (v nadaljevanju ZZZS) kot nosilec obveznega zdravstvenega zavarovanja sta pri reševanju finančnih težav zdravstvene blagajne posegla po kratkoročni strategiji, ki ne odpravlja strukturnih pomanjkljivosti, temveč zgolj blaži bolezenske znake in hkrati poglablja razsežnost pomanjkljivosti. Varčevalni ukrepi, ki so odraz prezadolženosti države in zdravstvene blagajne, ter prenos finančnega bremena iz javnih virov financiranja na zasebne predstavljajo osrednji del strategije, katere cilj je zagotavljanje finančne vzdržnosti sistema zdravstvenega varstva. Prenos finančnega bremena prezadolžene zdravstvene blagajne na zasebne vire financiranja oziroma v največji meri na dopolnilno zdravstveno zavarovanje je posledica znižanja odstotnega deleža plačil zdravstvenih storitev, ki je krit iz naslova obveznega zdravstvenega zavarovanja (zviševanje doplačil). ${ }^{31}$ Na ta način je država kratkoročno prenesla del finančnega bremena in družbene odgovornosti na zdravstvene zavarovalnice, ki pa so s hitrim odzivom in dvigom zavarovalnih premij breme nadalje prevalile na prebivalstvo. ${ }^{32}$ Država s povečevanjem odstotnega deleža kritja zdravstvenih storitev iz naslova dopolnilnega zdravstvenega zavarovanja dodatno povečuje njegovo vlogo in pomen v sistemu zdravstvenega varstva.

\section{ii) Visoka pokritost prebivalstva z dopolnilnim zdravstvenim zavarovanjem}

Konec leta 2012 je bilo v obvezno zdravstveno zavarovanje vključenih 2.076.273 zavarovanih oseb, od tega 1.536 .876 zavarovancev in 539.397 družinskih članov (ZZZS, 2013, str. 18). ${ }^{33}$ Dopolnilnozdravstveno zavarovanje je imelo leta 2012 v povprečju sklenjenih 1.431 .951 zavarovancev (Gracar, 2014, str. 14). Ker se nekaterim posameznikom ni treba vključiti v dopolnilno zdravstveno zavarovanje, saj imajo doplačila zdravstvenih storitev krita iz drugih naslovov (državnega proračuna, ${ }^{34}$ obveznega zdravstvenega zavarovanja $\left.{ }^{35}\right)$, je pokritost z dopolnilnim zdravstvenim

31 Za več o spremembah zakonodaje in ukrepih, ki jih je ZZZS sprejel na podlagi zakonodajnih sprememb; glej ZZZS (2012, str. 20-21).

32 Odličen primer takšne prakse je sprejem Zakona o uravnoteženju javnih financ (ZUJF) (Uradni list RS, št. 40/12). Zaradi zniževanja deleža kritja zdravstvenih storitev iz obveznega zdravstvenega zavarovanja, ki je bilo posledica sprejetja tega zakona, se je mesečna premija s 1. 7. 2012 pri vseh treh zdravstvenih zavarovalnicah dvignila za 15-20\%.

33 Po podatkih SURS je imela Slovenija 1. oktobra 2012 2.058.123 prebivalcev. To potrjuje skoraj popolno pokritost prebivalstva z obveznim zdravstvenim zavarovanjem.

34 Iz tega naslova imajo krita doplačila (24. in 25. ZZVZZ):

- priporniki, ki niso zavarovanci iz drugega naslova, obsojenci na prestajanju kazni zapora in mladoletniškega zapora, mladoletniki na prestajanju vzgojnega ukrepa oddaje v prevzgojni dom, osebe, ki jim je bil izrečen varnostni ukrep obveznega psihiatričnega zdravljenja in varstva v zdravstvenem zavodu ter obveznega zdravljenja odvisnosti od alkohola in drog;

- zavarovanci in po njih zavarovani družinski člani, ki nimajo zagotovljenega plačila zdravstvenih storitev $v$ celoti iz obveznega zdravstvenega zavarovanja, če izpolnjujejo pogoje za pridobitev denarne socialne pomoči, kar ugotavlja center za socialno delo;

- vojni invalidi;

- vojni veterani;

- žrtve vojnega nasilja.

35 Iz tega naslova imajo krita doplačila:

- otroci, učenci in študenti, ki se redno šolajo (posamezniki do dopolnjenega osemnajstega leta starosti oziroma v primeru rednega šolanja do šestindvajsetega leta starosti);

- otroci in mladostniki z motnjami v telesnem in duševnem razvoju; 
zavarovanjem ogromna. O tem priča tudi majhna razlika med obveznim in dopolnilnim zdravstvenim zavarovanjem (približno 105.000 oseb). Oktobra 2012 je po podatkih SURS in Ministrstva za delo, družino, socialne zadeve in enake možnosti v Sloveniji prebivalo 363.442 oseb, mlajših od osemnajst let, in 45.734 prejemnikov socialne pomoči. Seštevek mladoletnih oseb in prejemnikov socialne pomoči, ki mu prištejemo zavarovance, ki imajo sklenjeno dopolnilno zavarovanje, znaša več kot 1.800 .000 oseb. Če temu prištejemo še dijake in študente, stare med osemnajst in šestindvajset let, ki se redno šolajo, ${ }^{36}$ ter druge skupine prebivalstva, ki jim krije doplačila državni proračun, se močno približamo pokritosti z obveznim zdravstvenim zavarovanjem. S tem dokazujemo, da je $v$ dopolnilno zdravstveno zavarovanje vključeno skoraj celotno prebivalstvo Slovenije. Izjemno velika pokritost z dopolnilnim zdravstvenim zavarovanjem je značilna za vse države, ki imajo dopolnilno zdravstveno zavarovanje za doplačila uporabnikov (Francija, Belgija, Luksemburg) (Mossialos \& Thomson, 2009 , str. 27). Tako velika pokritost dodatno potrjuje pomembno vlogo dopolnilnega zdravstvenega zavarovanja v sistemu socialne varnosti in hkrati dokazuje njegovo močno socialno funkcijo.

\section{iii) Namen ustanovitve in narava dopolnilnega zdravstvenega zavarovanja}

Namen ustanovitve in narava dopolnilnega zdravstvenega zavarovanja sta prežeta z močno socialno konotacijo. Sistem financiranja zdravstvenega varstva temelji na obveznem zdravstvenem zavarovanju, ki pa ne krije vseh zdravstvenih storitev, temveč zgolj tiste, ki so določene z zakonom. ${ }^{37}$ Tudi delež kritja obveznega zdravstvenega zavarovanja se razlikuje glede na skupino, v katero je razvrščena posamezna storitev. $V$ celotni vrednosti krije le peščico zdravstvenih storitev, pri vseh drugih pa mora razliko do polne vrednosti doplačati zavarovanec neposredno ponudniku storitev. Višina doplačil variira med 10 in 90 \% vrednosti zdravstvene storitve. Določena doplačila so zaradi visoke cene zdravstvenih storitev tako visoka, da jih lahko uvrstimo v kategorijo »katastrofalnih« zdravstvenih izdatkov. Po podatkih Vzajemne so zneski nekaterih doplačil v prvi polovici leta 2013 dosegli naslednje vrednosti: najvišje doplačilo za zdravilo iz vmesne liste (90 \% vrednosti tega zdravila krije dopolnilno zdravstveno zavarovanje) je znašalo 9.579,11 evrov; povprečno doplačilo za zdraviliško zdravljenje je znašalo 832 evrov, medtem ko je znašalo najdražje kar 4.560 evrov; najvišje enkratno doplačilo za najzahtevnejše bolniške storitve, ki jih je potrebovalo več kot 8.000 zavarovancev (dopolnilno zdravstveno zavarovanje krije 10 \% njihove vrednosti), je znašalo 21.560 evrov (Mikeln, 2014). ${ }^{38}$ Posledica

- otroci in mladostniki z nezgodno poškodbo glave in okvaro možganov.

36 V študijskem letu 2011/2012 je bilo v Sloveniji v visokošolske študijske programe na univerzah in samostojnih visokošolskih zavodih vpisanih 89.600 študentov (SURS).

37 Glej 23. člen ZZVZZ.

38 Za boljšo predstavo o višini doplačil in finančnem tveganju, ki ga prinašajo, navajamo povprečno mesečno plačo in časovno obdobje, v katerem posameznik za zdravstveno varstvo nameni znesek v višini najvišjega enkratnega doplačila za najzahtevnejše bolniške storitve: posameznik, ki je v delovnem razmerju in prejema povprečno mesečno plačo (povprečna bruto plača je februarja 2014 znašala 1.520,88 evra), bi potreboval dobrih štirinajst let, da 
uvedbe doplačil oziroma tako visokih doplačil in velikega finančnega tveganja, ki ga doplačila prinašajo v primeru potrebe po zdravstvenih storitvah, je nastanek trga dopolnilnega zdravstvenega zavarovanja oziroma njegov razcvet. Posamezniki so zaradi izjemno visokih doplačil, z izjemo tistih, ki so nagnjeni k tveganju, prisiljeni skleniti dopolnilno zdravstveno zavarovanje, saj drugače tvegajo nastanek »katastrofalnih" zdravstvenih izdatkov. Iz narave dopolnilnega zdravstvenega zavarovanja in ureditve sistema doplačil izhaja, da dopolnilno zdravstveno zavarovanje nima vloge nadgradnje socialne oziroma zdravstvene varnosti, temveč je njen sestavni in bistveni element. Prav tako težko trdimo, da je vključitev v zavarovanje posledica avtonomne odločitve posameznika, saj višina doplačil skoraj onemogoča posameznikovo svobodno voljo. To potrjuje tudi izjemno visoka pokritost prebivalstva z zavarovanjem.

Glede na močno socialno funkcijo dopolnilnega zdravstvenega zavarovanja ter njegovo vlogo in pomen v sistemu zdravstvenega varstva in socialne varnosti lahko sklepamo, da je izvajanje te dejavnosti v javnem interesu.

\section{c) Oblastveni akt, s katerim je gospodarskim subjektom podeljena naloga storitve splošnega gospodarskega pomena z jasno opredeljenimi obveznostmi te naloge}

Podelitev naloge storitve splošnega gospodarskega pomena ne pomeni, da mora gospodarski subjekt nujno pridobiti za njeno izpolnjevanje izključno oziroma posebno pravico. Treba je razlikovati med posebno oziroma izključno pravico, podeljeno gospodarskemu subjektu za izvajanje določene storitve, in nalogo storitve splošnega gospodarskega pomena, ki ji je v okoliščinah posameznega primera lahko pripeta tudi izključna pravica. Izključna pravica služi gospodarskemu subjektu zgolj kot orodje, ki mu omogoča izpolnjevanje naloge storitve splošnega gospodarskega pomena. ${ }^{39}$ Za dodelitev naloge splošnega gospodarskega pomena se tako ne zahteva podelitev posebne oziroma izključne pravice, temveč zadostuje že oblastveni akt, s katerim se enemu ali celo vsem gospodarskim subjektom, ki izvajajo določeno storitev, dodeljujejo jasno opredeljene obveznosti. ${ }^{40}$ Takšen oblastveni akt predstavlja ZZVZZ, s katerim je bila ustanovljena in opredeljena storitev dopolnilnega zdravstvenega zavarovanja. Gospodarski subjekti morajo izvajati storitve ob spoštovanju posebnih obveznosti, ki so opredeljene v členih 62-62c ZZVZZ (enotno ocenjevanje oziroma enotna premija, odprti pristop in doživljenjsko kritje). Četrta točka prvega odstavka 62.b člena ZZVZZ nadalje opredeljuje predmet oziroma pravice iz dopolnilnega zdravstvenega zavarovanja, ki obsegajo kritje razlike med vrednostjo zdravstvenih storitev v skladu s členom 23 ZZVZZ in deležem te vrednosti, ki ga v skladu z istim členom krije

bi za zdravstveno varstvo (obvezno in dopolnilno zdravstveno zavarovanje - upoštevali smo višino zavarovalne premije Vzajemne, ki je marca 2014 znašala 27,62 evrov) porabil sredstva $\checkmark$ višini 21.560 evrov. $\vee$ tem izračunu je upoštevan samo prispevek obveznega zdravstvenega zavarovanja, ki bremeni neposredno delavca (6,36\% bruto plače). Ce pa pri izračunu upoštevamo tudi prispevek delodajalca, bi se časovno obdobje skrajšalo na slabih osem let.

39 Glej zadevo BUPA $[\mathrm{T}-289 / 03,179]$.

40 Glej zadevi Almelo [C-393/92, 47] in BUPA [T-289/03, 179]. 
obvezno zdravstveno zavarovanje, oziroma del te razlike, ko se doplačilo nanaša na pravico do zdravil z najvišjo priznano vrednostjo in medicinskih pripomočkov. Zakonodajalec tako ne določa zgolj obveznosti najosnovnejših storitev, ki bi zagotavljale, da bi storitve spoštovale najnižje standarde, temveč v celoti opredeli predmet dopolnilnega zdravstvenega zavarovanja oziroma zavarovalne proizvode, saj dopolnilno zdravstveno zavarovanje po zakonu ne sme vsebovati dodatnih storitev oziroma pravic. ${ }^{41}$ Za ta namen lahko zdravstvena zavarovalnica ustanovi dodatno zdravstveno zavarovanje, ki je ločena kategorija prostovoljnih zdravstvenih zavarovanj. Poleg navedenega je zakonodajalec izvajalcem dopolnilnega zdravstvenega zavarovanja v drugi točki člena 62(1) ZZVZZ naložil, da se morajo vključiti v izravnalno shemo dopolnilnega zavarovanja, s katero se med njimi izravnavajo razlike v stroških zdravstvenih storitev, ki izhajajo iz različnih struktur zavarovancev glede na starost in spol.

Sodišče je v zadevi BUPA odločalo o vprašanju, ali lahko štejemo Health Insurance Acts, ki podrobno opredeljujejo obveznosti zasebnega zdravstvenega zavarovanja (enotno ocenjevanje, odprti pristop, doživljenjsko kritje in najosnovnejše storitve, ki jih morajo spoštovati vsi izvajalci zasebnega zdravstvenega zavarovanja) kot oblastveni akt, s katerim je gospodarskim subjektom podeljena naloga storitve splošnega gospodarskega pomena z jasno opredeljenimi obveznostmi te naloge. Sodišče je na to vprašanje odgovorilo pritrdilno. ${ }^{42}$ Izhajajoč iz primerjave irske ureditve zasebnega zdravstvenega zavarovanja (Health Insurance Acts) in slovenske ureditve dopolnilnega zdravstvenega zavarovanja (ZZVZZ) lahko z gotovostjo trdimo, da tudi slovensko dopolnilno zdravstveno zavarovanje izpolnjuje kriterij oblastvenega akta, s katerim je gospodarskim subjektom podeljena naloga storitve splošnega gospodarskega pomena z jasno opredeljenimi obveznostmi te naloge. Ureditvi v obeh državah se namreč v smislu obveznosti, ki jih nalaga proučevana zakonodaja, skoraj povsem ujemata: enotno ocenjevanje, odprti pristop, doživljenjsko kritje in obseg storitev, ki jih morajo spoštovati vsi izvajalci zasebnega zdravstvenega zavarovanja, pri čemer je slovenska ureditev strožja, saj ne določa zgolj najosnovnejših storitev, temveč celoten obseg storitev oziroma pravic dopolnilnega zdravstvenega zavarovanja. Glede na zapisano lahko sklepamo, da je v primeru slovenskega dopolnilnega zdravstvenega zavarovanja podan oblastveni akt (ZZVZZ), s katerim je gospodarskim subjektom podeljena naloga storitve splošnega gospodarskega pomena z jasno opredeljenimi obveznostmi te naloge.

\section{d) Univerzalna in obvezna narava naloge storitve splošnega gospodarskega pomena}

Univerzalna narava storitve ne zahteva, da je storitev univerzalna v ožjem pomenu. ${ }^{43}$ Dejstvo, da ima od storitve korist le relativno omejena skupina

41 Irska zakonodaja nalaga gospodarskim subjektom, ki izvajajo zasebna zdravstvena zavarovanja, obveznost najosnovnejših storitev.

42 Glej zadevo BUPA [T-289/03, 174-176 in 182].

43 Značilno za obvezno zdravstveno zavarovanje. 
uporabnikov, ne postavlja nujno pod vprašaj univerzalne narave naloge te storitve ( $v$ našem primeru dopolnilnega zdravstvenega zavarovanja). ${ }^{44}$ Univerzalna narava tudi ne zahteva, da je dopolnilno zdravstveno zavarovanje brezplačno, oziroma ga je treba ponujati ne glede na ekonomsko donosnost. Nevključevanje prebivalstva zaradi nezadostnosti finančnih sredstev oziroma finančne nedostopnosti zavarovalnih premij ne spodkopava njegove univerzalne narave. Za to zadostuje, da se storitev ponuja vsem prebivalcem po enotnih in nediskriminatornih cenah ter pod enakimi pogoji in enake kakovosti. Univerzalna narava prav tako ni v nasprotju s svobodnim določanjem višine zavarovalnih premij izvajalcev dopolnilnega zdravstvenega zavarovanja. $\checkmark$ Sloveniji določajo višino zavarovalne premije dopolnilnega zdravstvenega zavarovanja zdravstvene zavarovalnice (tržne sile), kar lahko ob pomanjkanju regulacije vodi v visoke premije. Tveganje visokih premij, ki bi presegale finančne zmožnosti določenih skupin prebivalstva, je zaradi obveznosti enotnega ocenjevanja oziroma enotne cene premije ne glede na starost, spol in zdravstveno stanje zavarovancev ter konkurence med zavarovatelji $\checkmark$ praksi zelo omejeno. ${ }^{45} \mathrm{Kljub}$ omejenemu tveganju so cene zavarovalnih premij v zadnjih letih močno porastle. ${ }^{46}$ Predstavniki zdravstvenih zavarovalnic opozarjajo, da se cene nevarno približuje psihološko najvišji sprejemljivi vrednosti, ki naj bi znašala okoli 30 evrov. Porast cene zavarovalnih premij pa ni posledica »nedelovanja» tržnih mehanizmov in obveznosti storitve splošnega gospodarskega pomena, temveč državne politike, ki z namenom razbremenitve javnih sredstev prelaga finančno breme na zasebne vire financiranja.

Obvezna narava dopolnilnega zdravstvenega zavarovanja je prav tako bistveni pogoj za obstoj naloge storitve splošnega gospodarskega pomena. Obvezno naravo je treba razumeti tako, da morajo gospodarski subjekti, ki jim je z oblastvenim aktom zaupana naloga storitve splošnega gospodarskega pomena, to storitev načeloma ponujati na trgu ob spoštovanju posebnih obveznosti storitve splošnega gospodarskega pomena. Gospodarskim subjektom, ki izvajajo storitev dopolnilnega zdravstvenega zavarovanja, ni podeljena posebna oziroma izključna pravica, ki bi jim nalagala izvajanje te storitve ne glede na stroške, povezane z njenim izvajanjem. Kljub temu pa ZZVZZ, ki gospodarskim subjektom poverja izvajanje dejavnosti dopolnilnega zdravstvenega zavarovanja, določa dolžnost, da subjekti ponujajo to storitev vsem, ki zanjo zaprosijo. Sodišče EU je v zadevi BUPA zavzelo stališče, da sta obveznanaravastoritve in posledično nalogastoritve splošnega gospodarskega pomena podani, če mora ponudnik sklepati pogodbe pod določenimi pogoji, ki mu preprečujejo zavrnitev sopogodbenikov. ${ }^{47}$ Za izpolnitev pogoja obvezne narave storitve dopolnilnega zdravstvenega zavarovanja zadostuje že obveznost odprtega pristopa, ki je podana v členu 62.b(1) ZZVZZ. Obvezno

44 Takšno stališče je potrdilo Sodišče EU v zadevi BUPA [T-289/03, 187].

45 Tako je odločilo tudi Sodišče EU v zadevi BUPA [T-289/03, 202-203].

46 Z izjemo leta 2014, ko so vse tri zdravstvene zavarovalnice znižale premije: Vzajemna iz 27,76€ na 26,79 €, Triglav iz 28,54 € na 27,51 € in Adriatic Slovenica iz 28,34 € na 27,49 €.

47 Glej zadevo BUPA [T-289/03, 186-190]. 
naravo storitve dodatno utrjujejo tudi druge obveznosti dopolnilnega zdravstvenega zavarovanja, ki omejujejo diskrecijo zdravstvenih zavarovalnic: obveznost enotnega ocenjevanja, obveznost doživljenjskega kritja in opredelitev pravic iz naslova dopolnilnega zdravstvenega zavarovanja. ${ }^{48}$

Prostovoljna narava dopolnilnega zdravstvenega zavarovanja v smislu, da je vključitev v zavarovanje prepuščena svobodni izbiri zavarovancev, ni v nasprotju z univerzalno in obvezno naravo storitve. Univerzalna in obvezna narava nista pogojeni z obligatorno vključitvijo v dopolnilno zdravstveno zavarovanje. ${ }^{49}$ Dodatno dejstvo, ki govori v prid univerzalni in obvezni naravi dopolnilnega zdravstvenega zavarovanja, je tudi visoka pokritost prebivalstva z zavarovanjem. V zavarovanje je vključenih neposredno prek pogodbenega razmerja z zavarovateljem okoli 70 \% prebivalstva, če pa k temu prištejemo še prebivalstvo, ki ima kritje dopolnilnega zdravstvenega zavarovanja iz drugega, z zakonom določenega naslova, se delež močno približa pokritosti obveznega zdravstvenega zavarovanja.

Sodišče EU je $v$ zadevi BUPA $v$ kontekstu univerzalne in obvezne narave storitve presojalo tudi začetno čakalno dobo za vključitev v zavarovanje, ki je sestavni del slovenske ureditve dopolnilnega zdravstvenega zavarovanja (peta točka 62.b(1) člena ZZVZZ). Pri tem je zavzelo stališče, da so čakalne dobe za vključitev v dopolnilno zdravstveno zavarovanje bistveni element prostovoljnih zdravstvenih zavarovanj, ki temeljijo na obveznosti odprtega pristopa in enotnega ocenjevanja. Kljub temu da so čakalne dobe omejitev pri sklepanju zavarovanj, je to primerno sredstvo za usklajevanje dostopnosti in univerzalnosti storitve dopolnilnega zdravstvenega zavarovanja, saj onemogoča izkoriščanje medgeneracijske solidarnosti na način zlorab osebam, ki z vključitvijo v zavarovanje odlašajo, dokler nimajo precejšnje potrebe po zdravstvenih storitvah. ${ }^{50}$

Glede na stališče Sodišča EU v zadevi BUPA, kjer je odločilo, da je v primeru irskega zasebnega zdravstvenega zavarovanja podana univerzalna in obvezna narava naloge storitve splošnega gospodarskega pomena, ${ }^{51}$ ter analize slovenske ureditve dopolnilnega zdravstvenega zavarovanja lahko sklepamo, da je tudi v primeru slovenskega dopolnilnega zdravstvenega zavarovanja podana univerzalna in obvezna narava naloge storitve splošnega gospodarskega pomena.

\section{Zaključek}

Iz presoje slovenskega dopolnilnega zdravstvenega zavarovanja v luči meril za opredelitev dejavnosti kot storitve splošnega gospodarskega pomena, ki jih je izoblikovalo Sodišče EU, izhaja, da dopolnilno zdravstveno zavarovanje

\footnotetext{
48 Glej zadevo BUPA [T-289/03, 191-192].

49 Glej zadevo BUPA [T-289/03, 190-195] in pripadajočo sodno prakso.

50 Glej zadevo BUPA [T-289/03, 195-200].

51 Glej zadevo BUPA [T-289/03, 205-207].
} 
izpolnjuje vsa zahtevana merila. Dopolnilno zdravstveno zavarovanje ima gospodarsko naravo dejavnosti in se izvaja v javnem interesu kot nepogrešljiv del sistema zdravstvenega varstva (socialne varnosti). Analiza nadalje potrjuje tako podanost oblastvenega akta, s katerim je gospodarskim subjektom podeljena naloga storitve splošnega gospodarskega pomena z jasno opredeljenimi obveznostmi (ZZVZZ), kot tudi obvezno in univerzalno naravo dopolnilnega zdravstvenega zavarovanja. Glede na zapisano lahko zaključimo, da je slovensko dopolnilno zdravstveno zavarovanje storitev splošnega gospodarskega pomena, za katero velja omejen domet pravnega reda EU (pravil notranjega trga in konkurenčne zakonodaje). Takšna opredelitev pa ne upravičuje vsakršnih državnih regulatornih posegov v to dejavnost (npr. neposredno ali posredno dodeljevanje državnih sredstev subjektom, ki opravljajo storitve splošnega gospodarskega pomena - nadomestila za izvajanje javne storitve, različne obveznosti dopolnilnega zdravstvenega zavarovanja, pravila, ki zagotavljajo solventnost izvajalcev zdravstvenega zavarovanja itd.) temveč zgolj omogoča možnost za njihovo upravičevanje, ki je naslednji korak na poti presoje skladnosti pravne ureditve slovenskega dopolnilnega zdravstvenega zavarovanja s pravnim redom EU.

Bruno Nikolić je asistent za upravno-pravno področje na Fakulteti za upravo, Univerza v Ljubljani. Pri svojem raziskovalnem delu daje velik poudarek na ustavnem pravu, pravnem, političnem in socialnem vidiku EU in pravni ureditvi zdravstvenega varstva. 


\section{Viri in literatura}

Adriatic Slovenica d.d. (2012). Splošni pogoji dopolnilnega zdravstvenega zavarovanja.

Brezovnik, B. (2008). Izvajanje javnih služb in javno-zasebno partnerstvo. Maribor: Založba Lex localis.

Damjanovic, D., \& de Witte, B. (2009). Welfare values and welfare integration under the Lisbon Treaty. V: U. Neergaard, L. Roseberry \& R. Nielsen (ur.), Integrating welfare functions into EU law: From Rome to Lisbon (str. 53-94). Copenhagen: DJØF Publishing.

Evropska komisija. (2001). Sporočilo Komisije, Storitve splošnega interesa v Evropi (2001/C 17/04, z dne 19. 1. 2001).

Evropska komisija. (2007). Sporočilo Komisije Evropskemu parlamentu, Svetu, Evropskemu ekonomsko-socialnemu odboru in Odboru regij - Spremni dokument k Sporočilu: »Enotni trg za Evropo 21. stoletja«-Storitve splošnega interesa, vključno s socialnimi storitvami splošnega interesa: nova evropska zaveza, Bruselj, z dne 20. 11. 2007.

Evropska komisija. (2010). Priročnik za uporabo pravil Evropske unije o državnih pomočeh, javnih naročilih in notranjem trgu pri storitvah splošnega gospodarskega pomena, zlasti storitvah splošnega pomena na področju socialne varnosti (SEC(2010) 1545, z dne 7. 12. 2010).

Evropska komisija. (2011). Sklep Komisije o uporabi člena 106(2) Pogodbe o delovanju Evropske unije za državno pomoč v obliki nadomestila za javne storitve, dodeljenega nekaterim podjetjem, pooblaščenim za opravljanje storitev splošnega gospodarskega pomena (2012/21/EU, z dne 20. decembra 2011).

Gracar, I. (2014). Spremembe financiranja sistema zdravstvenega varstva RS, predlog z dne 24. 2. 2014.

Hatzopoulos, V. (2011). The concept of 'economic activity' in the EU Treaty: from ideological dead-ends to workable judicial concepts. Research papers in Law 06/2011. College of Europe, Department of European Legal Studies.

Mikeln, A. (2014). Pomen zasebnih sredstev za dolgoročno stabilnost zdravstvenega sistema. Prispevek na posvetu Zdravstvena polemika: Kakšna bo cena vašega zdravja v prihodnje. Ljubljana.

Milenkovič Kramer, A. (2009). Private health insurance in Slovenia: a study for the European Commmission.

Mossialos, E., \& Thomson, S. (2009). Private health insurance in the European Union. Final report prepared for the European Commission, Directorate General for Employment, Social Affairs and Equal Opportunities. LSE Health and Social Care, London School of Economics and Political Science.

Neergaard, U. (2013). The Concept of SSGI and Asymmetries Between Free Movement and Competition Law. V: U. Neergaard, E. Szyszczak, J. W. van de Gronden \& M. Krajewski (ur.), Social services of general interest in the EU - Legal issues of services of general interest (str. 205-245). The Hague: TMC Asser Press. DOI: 10.1007/978-90-6704-876-7_9

Pečarič, M., \& Bugarič, B. (2001). Javne službe. Ljubljana: Fakulteta za upravo.

Szyszczak, E. (2013). Soft Law and Safe Havens. V: U. Neergaard, E. Szyszczak, J. W. van de Gronden \& M. Krajewski (ur.), Social services of general interest in the EU-Legal issues of services of general interest (str. 317-345). The Hague: TMC Asser Press. DOI: 10.1007/978-90-6704-876-7_13 
SURS - Statistični urad RS. (2013). Izdatki za zdravstveno varstvo po namenih in virih financiranja, Slovenija, 2003-2012.

Šik, A. (2011). Obratovalni stroški dopolnilnega zdravstvenega zavarovanja. $\checkmark$ Dopolnilno zdravstveno zavarovanje in zdravstvena reforma. Ljubljana: Slovensko zavarovalno združenje.

van de Gronden, J. W. (2013). Free Movement of Services and the Right of Establishment. Does EU Internal Market Law Transform the provision of SSGI?. V: U. Neergaard, E. Szyszczak, J. W. van de Gronden \& M. Krajewski (ur.), Social services of general interest in the EU - Legal issues of services of general interest (str. 123-160). The Hague: TMC Asser Press. DOI: $10.1007 / 978-90-6704-876-7 \_6$

ZZZS - Zavod za zdravstveno zavarovanje Slovenije. (2012). Poslovno poročilo za leto 2011. Ljubljana: Zavod za zdravstveno zavarovanje Slovenije.

ZZZS - Zavod za zdravstveno zavarovanje Slovenije. (2013). Poslovno poročilo za leto 2012. Ljubljana: Zavod za zdravstveno zavarovanje Slovenije. 